\title{
PELESTARIAN AIR TANAH MELALUI TEKNOLOGI SUMUR PERESAPAN DI DESA MONTONG BAAN SELATAN KABUPATEN LOMBOK TIMUR
}

\author{
Humairo Saidah $^{1 *}$, Lilik Hanifah $^{1)}$, Heri Sulistyono ${ }^{1)}$, Salehuddin $^{1)}$ \\ ${ }^{1)}$ Jurusan Teknik Sipil FakultasTeknik Universitas Mataram \\ Jl. Majapahit No. 62 Matara, 83125 \\ *Korespondensi: h.saidah@unram.ac.id
}

\begin{abstract}
ABSTRAK
Semakin pesatnya pembangunan dan banyaknya alih fungsi lahan yang terjadi di Pulau Lombok, dikhawatirkan akan menimbulkan berbagai masalah lingkungan yang tidak diharapkan seperti banjir dan kekeringan. Berbagai langkah penanganan yang kongkrit perlu dilakukan, salah satunya adalah dengan membenahi sikap dan cara pandang masyarakat yang belum memahami tentang perlunya menjaga kelestarian air di wilayah ini. Oleh karena itu diperlukan sebuah gerakan penyadaran dengan penyebarluasan informasi dan ajakan kepada masyarakat untuk berpartisipasi aktif dalam melestarikan keberadaan air di muka bumi. Salah satunya adalah dengan memahamkan masyarakat melalui kegiatan penyuluhan tentang perlunya mengembalikan air ke dalam tanah dengan teknologi yang mudah dan sederhana yaitu sumur peresapan. Penyuluhan ini dimaksudkan untuk turut berkontribusi aktif terhadap upaya pencegahan bencana kekeringan yang sering terjadi di Pulau Lombok.
\end{abstract}

Kata kunci: Sumur peresapan, kekeringan, penyuluhan

\section{PENDAHULUAN}

Dalam kehidupan manusia, air adalah kebutuhan vital yang bagai mempunyai dua sisi mata pedang. Jika ketersediannya berlebihan maka dapat mengakibatkan bencana banjir dan tanah longsor. Sebaliknya jika ketersediaannya kurang, masalah kekeringan dapat menjalar menjadi bencana kelaparan dan penyebaran wabah penyakit.

Banyak hal yang perlu dibenahi mengenai sikap dan cara pandang sebagian masyarakat yang tidak atau belum mengerti atau bahkan tidak peduli terhadap keberadaan air di alam ini. Air yang menjadi sentral dari kehidupan manusia dipandang sebelah mata, padahal kebutuhan akan air tidak mungkin tergantikan dengan yang lain.
Oleh karena itu diperlukan sebuah gerakan penyadaran yang mengajak seluruh lapisan masyarakat untuk bersama-sama menanggulangi dan turut berpartisipasi aktif dalam melestarikan keberadaan air di alam untuk pemanfaatan yang sebesar-besarnya sekaligus pengen-dalian daya rusaknya.

Salah satu penyadaran yang dapat dilakukan adalah dengan mengajak masyarakat untuk sebanyak-banyaknya mengembalikan air ke bawah permukaan tanah dengan membuat sumur peresapan. Teknologi sumur peresapan ini selain dapat mengurangi potensi banjir di daerah pemukiman, juga dapat sekaligus mengisi kembali air ke dalam tanah sehingga dapat menambah cadangan air tanah serta memperbaiki kualitas air tanah.

Teknologi sumur peresapan ini sudah diwajibkan di beberapa kota besar di 
Indonesia, misal DKI Jakarta, Yogyakarta, Semarang, Bogor, dan lain-lain, karena terbukti secara signifikan bisa mengurangi debit limpasan permukaan dan mengurang potensi terjadinya banjir di lingkungan perumahan sekaligus mengisi kembali cadangan air tanah untuk mengantisipasi kekeringan di musim kemarau (BPPT, 2017). Hanya saja penyebar luasan informasi mengenai teknologi sumur peresapan ini dirasakan masih kurang, khususnya di lingkungan masyarakat di Nusa Tenggara Barat. Pemerintah daerah belum mensyaratkan pembuatan sumur peresapan ini pada masyarakat yang akan mendirikan bangunan.Sehingga hal ini dikhawatirkan akan menjadi potensi permasalahan drainase di masa yang akan datang.

Dengan semakin pesatnya pembangunan dan banyaknya alih fungsi lahan yang terjadi di Pulau Lombok, dikhawatirkan dapat menimbulkan berbagai masalah lingkungan yang tidak diharapkan seperti banjir di musim hujan dan kekeringan pada musim kemarau. Oleh karena itu penyuluhan ini dimaksudkan untuk turut berkontribusi aktif terhadap pencegahan salah satu potensi bencana lingkungan utamanya adalah bencana kekeringan yang sering menimpa masyarakat di Pulau Lombok pada umumnya dan di Kabupaten Lombok Timur khususnya.

\section{METODE KEGIATAN}

\section{Lokasi dan waktu pelaksanaan kegiatan}

Kegiatan penyuluhan dilaksakan pada tanggal 22 Oktober 2016 pada pukul 10.00 WITA bertempat di Balai Pertemuan Kantor Desa Montong Baan Selatan, Kecamatan Sikur, Kabupaten Lombok Timur, seperti terlihat pada Gambar 1.

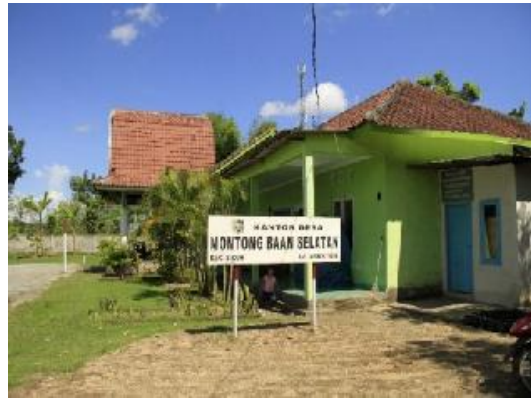

Gambar 1. Kantor Desa Montong Baan Selatan

\section{Metode kegiatan}

Kegiatan penyebarluasan informasi tentang sumur peresapan ini dilakukan melalui kegiatan penyuluhan. Penyuluhan dilakukan dengan metode ceramah yang dimulai dengan memberi penyadaran kepada masyarakat akan arti pentingnya menjaga kelestaran air dan ajakan untuk turut berkontribusi aktif dalam penyelamatan lingkungan.

Selanjutnya menjelaskan tentang perlunya pembuatan sumur peresapan untuk keperluan pengelolaan lingkungan yang berorientasi pada pencegahan bencana sekaligus menjaga keberlanjutan sumber daya air di masa yang akan datang.

Kemudian penjelasan dilanjutkan dengan menjelaskan Teknik pembuatan sumur meliputi informasi berbagai bahan yang dapat digunakan untuk membuat sumur peresapan serta standar teknis perencanaannya.

Tahap terakhir adalah sesi diskusi dan tanya jawab. Pada tahap ini masyarakat diberi keluasan untuk mengkonsultasikan berbagai hal yang belum dipahami tentang tata cara pembuatan sumur yang sesuai SNI yang berlaku..

\section{HASIL DAN PEMBAHASAN}

\section{Materi penyuluhan}

Sumur peresapan merupakan upaya sederhana teknik konservasi air yang berupa bangunan berbentuk sumur gali 
yang diisi dengan bahan-bahan resapan (pasir, batu dan ijuk) secara berlapis sampai rata dengan permukaan tanah yang berfungsi sebagai tempat peresapan air ke dalam tanah.

Pembuatan bangunan sumur resapan dimaksudkan untuk memberikan imbuhan air (recharge) secara buatan dengan cara memasukkan air hujan ke dalam tanah. Tak hanya sangat baik diterapkan pada daerah yang didominasi permukaan impervious misalnya kawasan pemukiman, pertokoan, industri juga prasarana umum lainnya, namun juga sangat perlu diaplikasikan pada daerah resapan guna sebanyak-banyaknya mengambalikan air ke dalam tanah untuk keperluan konservasi lingkungan dan air.

Sumur peresapan dapat mengatasi permasalahan air hujan yang jatuh di kawasan pemukiman serta dapat membantu melestarikan atau menyeimbangkan tanah, menambah potensi air tanah, mengurangi meluasnya penyusupan/interusi air laut ke daratan, mengurangi meluasnya genangan banjir, mengurangi timbulnya penurunan air tanah, melestarikan dan menyelamatkan sumber daya air untuk jangka panjang (Litbang PUPR, 2017)

Menurut SNI 03-2453-2002 Tata Cara Perencanaan Sumur Resapan Untuk Lahan Pekarangan dan Suripin (2004) memuat berbagai parameter perencanaan di antaranya:

\section{A. Persyaratan Sumur Peresapan}

Sekalipun sumur resapan banyak mendatangkan manfaat, namun dalam pembuatannya harus memperhatikan syaratsyarat yang diperlukan untuk mendapatkan hasil yang optimal. Berikut ini persyaratan umum dalam pembuatan sumur peresapan :

1. Sumur resapan air hujan harus dibuat pada lahan yang lolos air dan tahan longsor.

2. Sumur resapan air hujan harus bebas kontaminasi/pencemaran limbah, baik domestik maupun industri.
3. Air yang masuk sumur resapan adalah air hujan.

4. Untuk daerah sanitasi lingkungan buruk, sumur resapan air hujan hanya menampung air atap dan disalurkan melalui talang langsung masuk ke dalam sumur

5. Mempertimbangkan aspek hidrologi.

B. Pemilihan lokasi Sumur Peresapan

Kusnaedi (1996) menyebutkan dalam perencanaan pembuatan sumur resapan perlu memperhitungkan berbagai faktor, diantaranya iklim, kondisi air tanah, penutupan lahan, dan kondisi sosial masyarakat. Faktor iklim yang perlu mendapat perhatian adalah besarnya curah hujan. Semakin besar curah hujan di suatu wilayah berarti semakin besar sumur resapan yang diperlukan. Jenis tanah akan menentukan kecepatan peresapan air di dalam tanah. Kondisi penutupan lahan mempengaruhiprosentase air yang akan meresap dalam tanah. Sedangkan kondisi sosial ekonomi masyarakat lebih terkait dengan pemilihan jenis bahan pembuat sumur resapan oleh masyarakat.

1. Keadaan muka air tanah

Kedalaman muka air tanah sangat mempengaruhi efektifitas peresapannya. Makin dalam muka air tanah, makin ada ruang air untuk teresapkan sehingga proses peresapan bias lebih efektif. Pada kondisi permukaan air tanah yang dalam, sumur resapan juga dapat membantu memulihkan ketersediaan air tanah, sehingga dimensi dapat atau bahkan perlu dibuat sebesarbesarnya. Sebaliknya pada lahan yang muka airnya dangkal, proses peresapannya menjadi kurang efektif dan tidak akan berfungsi dengan baik, utamanya pada daerah rawa dan pasang surut (Mulyana 1998).

Untuk mengatahui kedalaman muka air tanah dilakukan dengan cara pengukuran atau pengamatan langsung di daerah calon lokasi sumur dibangun. Bisa menggunakan sumur gali milik masyarakat setempat sebagai referensi kedalaman air tanah, yang diukur dari permukaan tanah sampai 
permukaan airnyadan dilakukan pada musim penghujan. Syarat minimum kelayakan dibangunnya sumur peresapan adalah, muka air tanah setempat harus $\geq 1,50 \mathrm{~m}$ pada musim penghujan.

2. Permeabilitas tanah

Menurut Mulyana (1998), sifat fisik tanah sangat berpengaruh pada daya resap tanah terhadap air hujan. Sifat fisik yang langsung berpengaruh terhadap besarnya infiltrasi adalah tekstur dan pori-pori tanah. Tanah berpasir dan porus lebih mampu menginfiltrasikan air hujan dengan cepat. Angka permeabilitas tanah yang disyaratkan dalam pembuatan sumur peresapan adalah $\geq 2,0 \mathrm{~cm} / \mathrm{jam}$. Secara umum permeabilitas tanah yang layak untuk dibangun sumur resapan di bagi tiga kelas sebagai berikut:

a. Permeabilitas tanah sedang(lanau, 2,0$6,5 \mathrm{~cm} / \mathrm{jam})$

b. Permeabilitas tanah agak cepat (pasir halus, $6,5-12,5 \mathrm{~cm} / \mathrm{jam}$ )

c. Permeabilitas tanah cepat (pasir kasar, lebih besar $12,5 \mathrm{~cm} / \mathrm{jam}$ )

Sedangkan berdasarkan jenis tanahnya, dapat dibedakan angka permeabilitas dengan kecepatan infiltrasinya (Arsyad (1976) dalam Arafat (2008) (Tabel 1).

Tabel 1. Kecepatan infiltrasi menurut jenis tanah

\begin{tabular}{|c|c|c|}
\hline $\begin{array}{l}\text { Jenis } \\
\text { Tanah }\end{array}$ & $\begin{array}{l}\text { Kecepatan } \\
\text { Infiltrasi } \\
(\mathrm{mm} / \mathrm{jam})\end{array}$ & Kriteria \\
\hline $\begin{array}{l}\text { Pasir } \\
\text { berlempung }\end{array}$ & $25-30$ & $\begin{array}{l}\text { sangat } \\
\text { cepat }\end{array}$ \\
\hline Lempung & $12.5-25$ & cepat \\
\hline $\begin{array}{l}\text { Lempung } \\
\text { berdebu }\end{array}$ & $7.5-15$ & sedang \\
\hline $\begin{array}{l}\text { Lempung } \\
\text { berliat }\end{array}$ & $0.5-2.5$ & lambat \\
\hline Liat & $<0.5$ & $\begin{array}{l}\text { sangat } \\
\text { lambat }\end{array}$ \\
\hline
\end{tabular}

Selain persyaratan kedalaman muka air tanah dan permeabilitas tanah, penempatan sumur resapan juga harus diperhatikan. Letak sumur peresapan sebaiknya mengikuti persyaratan seperti disajikan dalam Tabel 2.

Tabel 2. Jarak minimal pembuatan sumur resapan

\begin{tabular}{clc}
\hline No & Bangunan atau Objek & $\begin{array}{c}\text { Jarak } \\
(\mathrm{m})\end{array}$ \\
\hline 1. & Pondasi Bangunan/rumah & 1 \\
2. & Sumur untuk air minum & 3 \\
3. & Tangki septik & 5 \\
\hline
\end{tabular}

Sumber: Anonim, 2002.

\section{Pelaksanaan Penyuluhan}

Kegiatan ini dilaksanakan oleh tim Pengabdian yang melibatkan mahasiswa yang sedang melakukan Kuliah Kerja Nyata di desa montong Baan Selatan. Tim bekerja bersama Kepala Desa dan staf desa yang secara langsung turut mempersiapkan dan membantu tim dalam pelaksanaan acara penyuluhan.

Penyuluhan dihadiri oleh setidaknya 40 orang warga dari berbagai lapisan masyarakat, mulai dari Kepala desa beserta perangkat desa, anggota Babinsa, guru, tokoh pemuda, mahasiswa, para ibu rumah tangga dan bahkan anak-anak.

Keberhasilan kegiatan ini terlihat dari tingginya tingkat kehadiran masyarakat menghadiri kegiatan penyuluhan. Materi yang disampaikan juga diserap dengan baik terlihat dari banyaknya umpan balik berupa pertanyaan baik tentang teknis pembuatan sumur yang benar maupun berbagai hal yang berkaitan dengan kegiatan pelestarian air secara umum. 


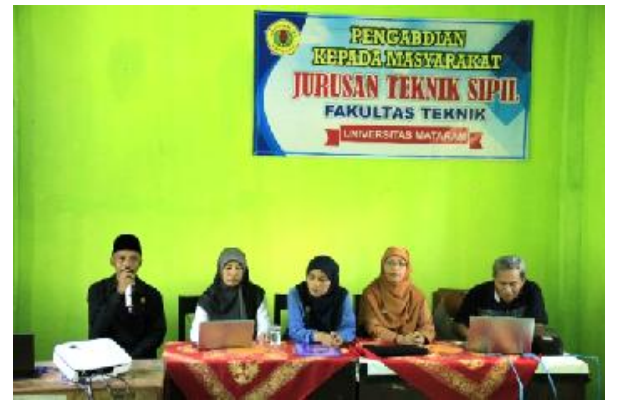

Gambar 2. Pembukaan acara penyuluhan oleh Kepala desa Montong Baan Selatan beserta seluruh tim penyuluh

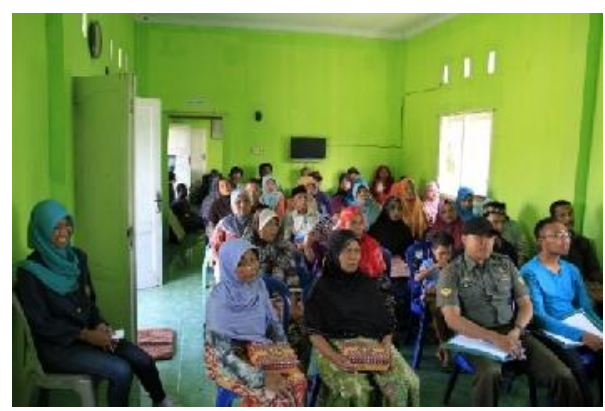

Gambar 3. Peserta penyuluhan

Acara penyuluhan juga berlangsung tertib dan lancar. Masyarakat dengan tertib dan tenang mendengarkan dan memperhatikan paparan materi yang disampaikan tim penyuluh dan bahkan tampak antusias serta terlibat sangat aktif dalam diskusi dan tanya jawab di sesi akhir acara.

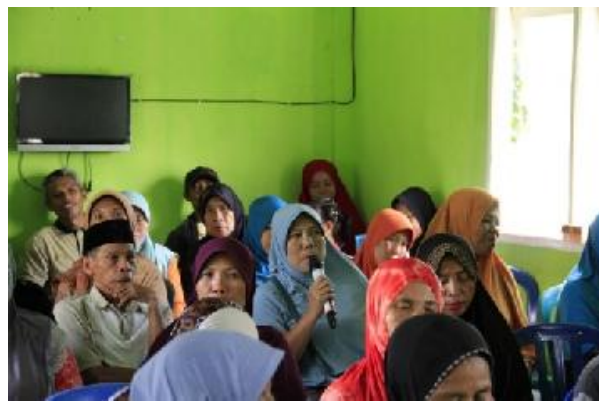

Gambar 4. Antusiasme peserta bertanya
Berdasarkan hasil diskusi diperoleh informasi dari masyarakat bahwa secara umum masyarakat Desa Montong Baan Selatan belum memahami arti penting dari pembuatan sumur peresapan maupun tata cara pembuatannya. Sehingga kegiatan penyuluhan ini sangat relevan untuk terus disebarluaskan guna terus mengedukasi masyarakat luas sekaligus menggugah kesadaran masyarakat untuk lebih berperan aktif dalam pelestarian alam dan lingkungannya dan sumberdaya air khususnya.

Langkah lanjutan untuk memantau kegiatan penyuluhan ini masih harus terus dilakukan, yaitu dengan pemanduan langsung pembuatan sumur peresapan untuk melihat secara langsung kendala teknis di lapangan. Tetapi karena hal itu belum terlaksana mengingat keterbatasan waktu yang ada, maka masih belum dapat disampaikan hasil lengkap pelaksanaan kegiatan penyuluhan ini.

Secara umum kegiatan ini telah membuka wawasan masyarakat tentang perlunya menjaga kelestarian air di muka bumi, beserta sumbangsih kongkrit yang dapat masyarakat berikan dalam upaya ini. Selanjutnya masyarakat mengharap kehadiran tim kembali untuk simulasi pembuatan sumur peresapan agar dapat memantau kendala teknis yang mungkin ditemui selama pembuatan..

\section{KESIMPULAN DAN SARAN}

Kegiatan penyuluhan tentang pentingnya pelestarian air melalui berbagai langkah nyata masih sangat dibutuhkan oleh mayarakat, mengingat masyarakat belum sepenuhnya menyadari hal kecil yang sebetulnya berdampak besar bagi kelestarian alam.

Penyuluhan tentang pembuatan sumur peresapan telah membuka wawasan masyarakat tentang bagaimana cara membangun sumur peresapan yang benar 
yang sesuai standar perencanaan SNI yang berlaku.

\section{DAFTAR PUSTAKA}

Anonim, 2002.Tata Cara Perencanaan Sumur Resapan Air Hujan Untuk Lahan Pekarangan. SNI 03-2453, Badan Standarisasi Nasional, Jakarta.

Arafat Y, 2008. Reduksi Beban Aliran Drainase Permukaan Menggunakan Sumur Resapan. Jurnal SMARTek. 6(3): 144-153.

BPPT, 2017. https://www.bppt.go.id /profil/organisasi/36-berita-bppt3/berita-teknologi-sumberdaya-alamkebencanaan/289-sumur-resapansolusi-pencegahan-banjir-jakarta. Diakses : 21 Pebruari 2017.

Karmawan, Darmanto, Widanarko, Sopian dan Nasrullah, 1997.Drainase Perkotaan. Universitas Gajah Mada, Yogyakarta.

Kusnaedi, 1996. Sumur Resapan untuk Permukiman Perkotaan dan Pedesaan. Penebar Swadaya, Jakarta.

Litbang PUPR, 2017. Sumur Resapan Air Hujan,http://eproduklitbang.pu.go.id/su mur-resapan-air-hujan/. Diakses :15 April 2017.

Mulyana R, 1998. Penentuan Tipe Konstruksi Sumur Resapan Berdasarkan Sifat-Sifat Fisik Atanh Dan Kondisi Sosial Ekonomi Masyarakat Di Kawasan Puncak. Tesis, Institut Pertanian Bogor, Bogor.

Suripin, 2004. Sistem Drainase Perkotaan yang Berkelanjutan. Andi, Yogyakarta. 